\title{
Triple positivity of HBsAg, anti-HCV antibody, and HIV and their influence on CD4+ lymphocyte levels in the highly HIV infected population of Abeokuta, Nigeria
}

\author{
Sandra Olukemi Ogwu-Richard ${ }^{1}$, David Ajiboye Ojo ${ }^{1}$, Olusola Abiodun Akingbade ${ }^{1,2}$, \\ Iheanyi Omezuruike Okonko ${ }^{3}$
}

1. Department of Microbiology. Federal University of Agriculture, Abeokuta, Ogun State, Nigeria.

2. Department of Microbiology, Federal Medical Centre Idi Aba, Abeokuta, Ogun State, Nigeria.

3. Medical Microbiology Unit,Department of Microbiology, University of Port Harcourt, East-West Road, P.M.B. 5323, Choba, Port Harcourt, Rivers State, Nigeria.

\begin{abstract}
Background: Few studies exist on hospital-based seroprevalence of triple positivity of HIV/HBV/HCV in Nigeria.

Objectives: The study aimed at determining the triple positivity of HIV, HBsAg and HCV among HIV-infected individuals in Abeokuta, Nigeria and defining the influence of these triple infections on CD4+ counts of HIV-infected individuals as antiretroviral therapy improves in Nigeria.

Methods: Enumeration of CD4+ levels in 183 HIV-infected persons was done with Partec Flow Cytometer. Seropositivity of HBsAg and anti-HCV antibody was detected with rapid kits.

Results: From the result obtained, significance variance $(\mathrm{p}<0.05)$ existed between HIV positive persons and persons who tested positive to HIV/HBV/HCV triple infection before and after the commencement of HAART. Of these infections, $31(16.9 \%)$ had HBV/HCV/HIV triple infection, while 152(83.1\%) had HIV mono infection only, 56(30.6\%) had HBV/ HIV dual infection only and 43(23.5\%) had HCV/HIV dual infection only. Significant variance $(\mathrm{p}<0.05)$ also existed be-

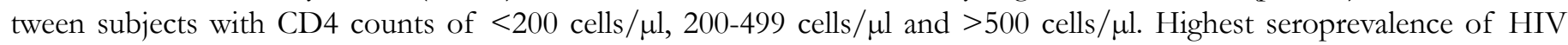
$(35.0 \%)$ was found in age groups $35-44$ years and $>65$ years had the least $(2.7 \%)$. Significant variance $(\mathrm{p}<0.05)$ also existed in the progression of CD4+ lymphocytes cells between subjects with persistent decrease $(32.3 \%)$ in CD4+ lymphocytes cells and those with fluctuation in their CD4+ lymphocytes cells (12.9\%) after the commencement of ART.

Conclusion: The study further confirms that triple positivity of HIV/HBV/HCV infection is common in Abeokuta, Nigeria. Testing of these triple infections should be a big concern in the best choice and commencement of ART. Also, the study showed that consistent and prolonged use of HAART had a positive impact on the CD4 count of HIV-infected individuals. Keywords: AIDS, ART, HAART, CD4, HIV/HBV/HCV

DOI: http://dx.doi.org/10.4314/ahs.v15i3.4

Cite as: Ogwn-Richard SO, Ojo DA, Akingbade OA, Okonko IO. Triple positivity of HBs Ag, anti-HCV antibody, and HIV and their influence on CD4+ lymphocyte levels in the highly HIV infected population of Abeokuta, Nigeria. Afri Health Sci. 2015;15(3):719-27. doi: bttp://dx.doi.org/10.4314/abs.v15i3.4
\end{abstract}

\section{Introduction}

Dual or triple infections with human immunodeficiency virus (HIV), hepatitis $\mathrm{B}$ and $\mathrm{C}$ viruses (HBV and $\mathrm{HCV}$ ) remain a major public health concerns as most
Corresponding author:
Iheanyi Omezuruike Okonko
Medical Microbiology Unit,
Department of Microbiology,
University of Port Harcourt,
East-West Road, P.M.B. 5323, Choba,
Port Harcourt, Rivers State, Nigeria;
Tel.: +2348035380891
Email: mac2finney@yahoo.com,
iheanyi.okonko@uniport.edu.ng

drugs have considerably enhanced the control and/or management of single infections ${ }^{1}$. There is increasing evidence that triple infections of $\mathrm{HIV} / \mathrm{HBV} / \mathrm{HCV}$ is a common unrestricted health issues ${ }^{2}$ which affects the clinical course of the disease ${ }^{3-4}$. They are overwhelming disease agents that shared modes of transmission ${ }^{5-7}$, thus HIV infected individuals are at risk of dual or triple infections with $\mathrm{HBV}$ and $\mathrm{HCV}$ infections ${ }^{8}$. Long-lasting infections with HIV, HBV, and HCV are major public health problems ${ }^{6}$ which may potentially be as a result of virological interactions and could have an underlying immunological mechanism ${ }^{4,9-10}$.

Dual infections with $\mathrm{HIV} / \mathrm{HBV}$ or $\mathrm{HIV} / \mathrm{HCV}$ and triple infections with $\mathrm{HIV} / \mathrm{HBV} / \mathrm{HCV}$ is also vastly prevailing among intravenous drug users (IDUs) ${ }^{11-13}$. Amongst the transmissible blood-borne viruses through 
the parenteral route (blood transfusion and sexual intercourse), HIV, HBV and HCV are significant and have numerous consequences ${ }^{6,13-15}$. However, epidemiology of HIV-HBV-HCV triple infections varies as a result of differences in background of hepatitis infections and routes of HIV transmission ${ }^{16}$. These viruses does not merely create asymptomatic tenacious infections with chance sequelae, nevertheless they similarly lead to major illness and death when spread by transfusion ${ }^{6,17}$.

Immunologically, the incursion of the human body by any of HIV, HBV or HCV is initially known to innate immunity, thereafter to the cellular and humoral immune reaction ${ }^{7,18-22}$. Furthermore, cellular and humoral immunity consist of cluster of differentiation-4+ (CD4+) T-helper cells-1 and cytotoxic CD8+T-cells which mark and fix endogenously treated viral proteins which are conveyed on the superficial of diseased hepatocytes, and are ultimately disintegrate on the long $\operatorname{run}^{7,23-24}$. This facilitates shedding of HIV, HBV and HCV from the body of immunocompetent ill persons. This leads to immune-intermediated hepatocytes (liver) impairment ${ }^{7,25}$. The explicit cellular and humoral immune reaction is consist of antibodies targeted at particular antigens of $\mathrm{HIV}, \mathrm{HBV}$ and $\mathrm{HCV}^{7}$. The absence or presence of anti-HCV antibodies or HBsAg is measurable by particular laboratory investigations, besides, they consequently function as dependable markers of normal infection, which are valuable in epidemiology of HIV, HBV and HCV7, ${ }^{26-29}$.

In the case of $\mathrm{CD} 4+$, which is a glycoprotein conveyed on the exterior of regulatory $\mathrm{T}$ cells, T-helper cells, dendritic cells, monocytes and macrophages and; they are the primary target for HIV ${ }^{30}$. The CD4+ T-lymphocytes cells however, are used to measure disease progression and to decide the commencement of ART ${ }^{31}$. HIV leads to a consistent decrease in CD4+ T-lymphocytes cells. Majority of people with HIV have been observed to have fallen in the CD4+ T-lymphocytes cells over time. Persons with AIDS show T-cell lymphopenia, a forfeiture of CD4+ lymphocytes and comparative proliferation in CD8+subtype and in the CD3+CD4-CD8- subtype $^{31}$. A clear-cut count of CD4+T cells is essential for dependable and well-ordered antiretroviral therapy (ART) and monitoring ${ }^{31}$. Therefore, the CD4+lymphocytes count is useful to monitor the immune system, when to start HIV treatment and effectiveness of HIV treatment ${ }^{32}$.
Highly active antiretroviral therapy (HAART) has distorted HIV and AIDS from a consistently deadly ailment into a controllable long-lasting infection and has been presented to reinstate CD4+ cells in HIV positive persons $^{8,33,34}$. The achievements of HAART might be conceded by dual or triple infections with hepatitis viruses as they are recognized to have antagonistic consequences on the scenario of HIV and hepatitis infections ${ }^{8,34,35}$. Subsequently, improved attention has to be paid on dual or triple infections of hepatitis viruses and HIV particularly in the emerging countries such as $\mathrm{Ni}$ geria where these sets of viruses are prevalent8.

While the proportion of individuals with dual or triple positivity is lesser, the blend of HIV and HBV and/or $\mathrm{HCV}$ is a precarious co-existence $\mathrm{e}^{6,36-38}$ and might devise a damaging consequence on the infected persons and the outcome of treatment6]. Dual or triple infections with HBV or HCV upsurges the menace for hepatotoxicity of HAART and possibility of inception of an AIDS-defining illness, likened with infection with HIV only ${ }^{8,34,35,39}$. Studies previously have proposed that dual positivity of HIV/HBV or HIV/HCV and triple positivity $\mathrm{HIV} / \mathrm{HBV} / \mathrm{HCV}$ have dampened immune reaction to HAART likened with those with only HIV ${ }^{40-42}$. While others studies have reported some degrees of immune reinstatement in individuals with $\mathrm{HIV} / \mathrm{HBV}$ or HIV/HCV dual-infection ${ }^{42-48}$. Management of either hepatitis virus is multifaceted because of pharmacokinetic interfaces with constituents of HAART regimens. Hence, the marvel of HIV and hepatitis viruses' dual or triple infections is a cause for concern ${ }^{8}$.

Although the HIV dual or triple infections with HBV and/or HCV has been documented globally in persons prone to blood-borne diseases, restricted data are obtainable on the degree of dual or triple infection and consequence of these viruses on the immune system in emerging countries8]. Nigeria fits to the set of countries vastly prevalent for viral hepatitis ${ }^{49}$. Limited studies have been completed on HIV, HBV, HCV individually in Nigeria nevertheless the information about the interrelationship between these viruses and their consequence on the immune system remains vague ${ }^{8}$.

Thus, the study aimed at determining the triple positivity of $\mathrm{HIV} / \mathrm{HBV} / \mathrm{HCV}$ in $\mathrm{HIV}$-infected persons in Abeokuta, Nigeria. The study also aimed at defining the impact of these infections on CD4+ counts among $\mathrm{HIV}$-infected persons as antiretroviral therapy improves in Nigeria. 


\section{Methodology}

\section{Study area and population}

The present study was carried out at the Federal Medical Centre, Idi-Aba, Abeokuta, Ogun State, Nigeria. One hundred and eighty three (183) HIV-positive persons participated in the study, one hundred were females while 83 were males. Participants were confirmed HIV-positives, ages 15 years and above. Approval was obtained from the Ethics Committee of the hospital. Participants also gave their consents and pertinent confidentiality was kept all through the study.

\section{Sample collection and preparation}

Venous blood from the $183 \mathrm{HIV}$-infected persons were obtained into plain tubes without any anti-coagulants. Sera from the venous blood was obtained by spinning for $5 \mathrm{~min}$ at 2000 resolution per minutes (rpm). The decanted sera were kept at $-20 \mathrm{oC}$ for serological analysis. In the same vein, another four millilitres $(4 \mathrm{ml})$ of blood was collected into an EDTA anti-coagulated tube for enumeration of CD4+ cells.

\section{Serologic assay}

The whole samples were retested using HIV rapid kits (Bioline Standard Diagnostic Inc, Korea). It is a quick immunochromatography technique for detecting $\operatorname{IgA}$, IgG and IgM antibodies specific to HIV-1/2 concurrently in serum. A red colour line in the patient and control windows is indicative of seropositivity while the existence of the red-coloured line in the control and its non-appearance in the patient window is indicative of seronegativity.

The samples were also screened for HBsAg and an-
ti-HCV antibody using ACON HBsAg and anti-HCV antibody test kits respectively. This is a membrane-based immunoassay (manufactured by ACON Lab., Inc. San Diego, USA). In this kit, the test region had been previously coated with recombinant $\mathrm{HBsAg}$ and $\mathrm{HCV}$ antigen. Both kits are based on chromatographics vessel movement to form coloured lines. The existence of coloured line is indicative of seropositivity while its non-appearance is indicative of seronegativity.

Assay for the CD4+ lymphocytes cells were carried out using the Partec Flow Cytometer (CyFlow counter). This is a fluorometric method used to differentiate and count cells present in the sample. Cells in suppression pass through in flow curvette in a narrow stream. Finally fluorescence signal are segmentally generated and signal are detected and displayed. The CD4 levels of each patient were examined at initial visit and then three months and six months after commencement of ART treatment.

\section{Data analysis}

The proportions of participants with triple infection of $\mathrm{HIV} / \mathrm{HBV} / \mathrm{HCV}$ were calculated. CD4+ counts of individuals infected with $\mathrm{HIV} / \mathrm{HBV} / \mathrm{HCV}$ were presented in figures with sex, age and the CD4+ count progression as well as their response to ART. Relevant chi-square statistics were calculated to complement each result using SPSS 20.0 window packages.

\section{Results}

In the present study, $183 \mathrm{HIV}$-infected individuals were examined (Table 1). Of which, 100 (54.6\%) were females and $83(45.4 \%)$ were males.

Table 1: Sex and Age Distribution of HIV-Infected Subjects

\begin{tabular}{ll}
\hline Risk factors & Number (\%) \\
\hline Sex & \\
\hline Males & $83(45.4)$ \\
Females & $100(54.6)$ \\
Age & \\
\hline $15-24$ & $33(18.0)$ \\
$25-34$ & $42(23.0)$ \\
$35-44$ & $64(35.0)$ \\
$45-54$ & $29(15.8)$ \\
$55-64$ & $10(5.5)$ \\
$65-74$ & $5(2.7)$ \\
\hline Total & $\mathbf{1 8 3 ( 1 0 0 . 0 )}$ \\
\hline
\end{tabular}


Higher percentages of HIV positives were in age group $35-54$ years $(35.0 \%)$ while age group $65-74$ years $(2.7 \%)$ had the least as shown in Table 1. Significant difference $(p<0.05)$ existed between sex, age and seropositivity of HIV.
Of these $183 \mathrm{HIV}$-infected subjects, 152(83.1\%) had HIV mono infection only, 56(30.6\%) HBV/HIV dual infection only and $43(23.5 \%)$ had HCV/HIV dual infection only and $31(16.9 \%)$ had HBV/HCV/HIV triple infection. Figure 1 shows the sex-related seroprevalence of triple infections of $\mathrm{HIV} / \mathrm{HBV} / \mathrm{HCV}$.

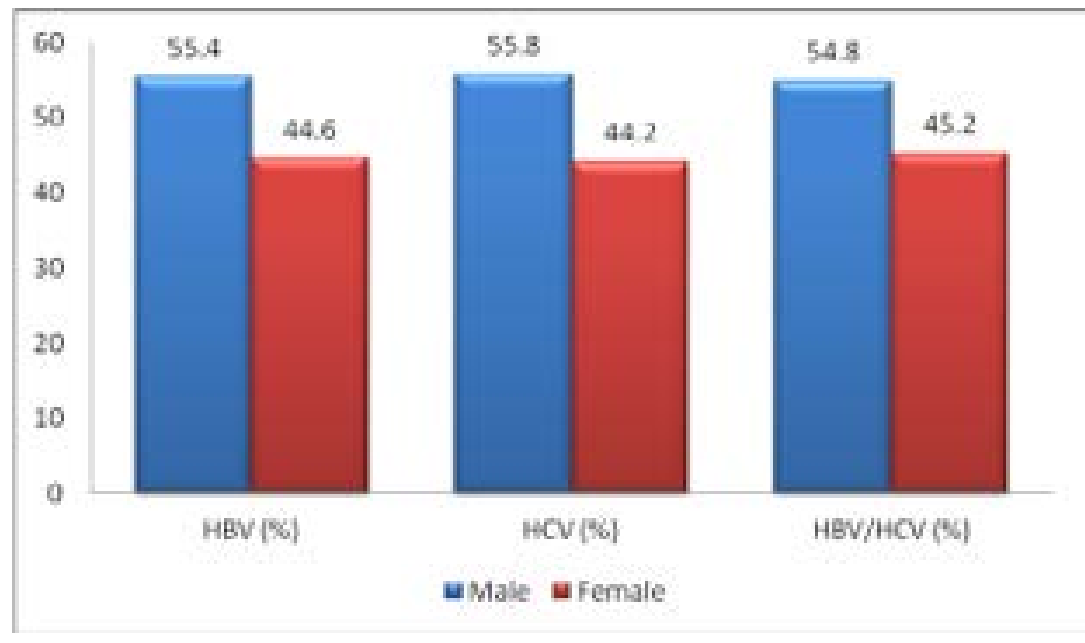

Figure 1: Sex- related seroprevalence of $\mathrm{HIV} / \mathrm{HBV} / \mathrm{HCV}$ triple infections

The sex-related seropositivity revealed higher seropositivity of $\mathrm{HIV} / \mathrm{HBV} / \mathrm{HCV}$ in males (54.8\%)] compared to females $(45.2 \%)$. However, no significant variance $(\mathrm{p}>0.05)$ existed between sex and triple infections of $\mathrm{HIV} / \mathrm{HBV} / \mathrm{HCV}$.

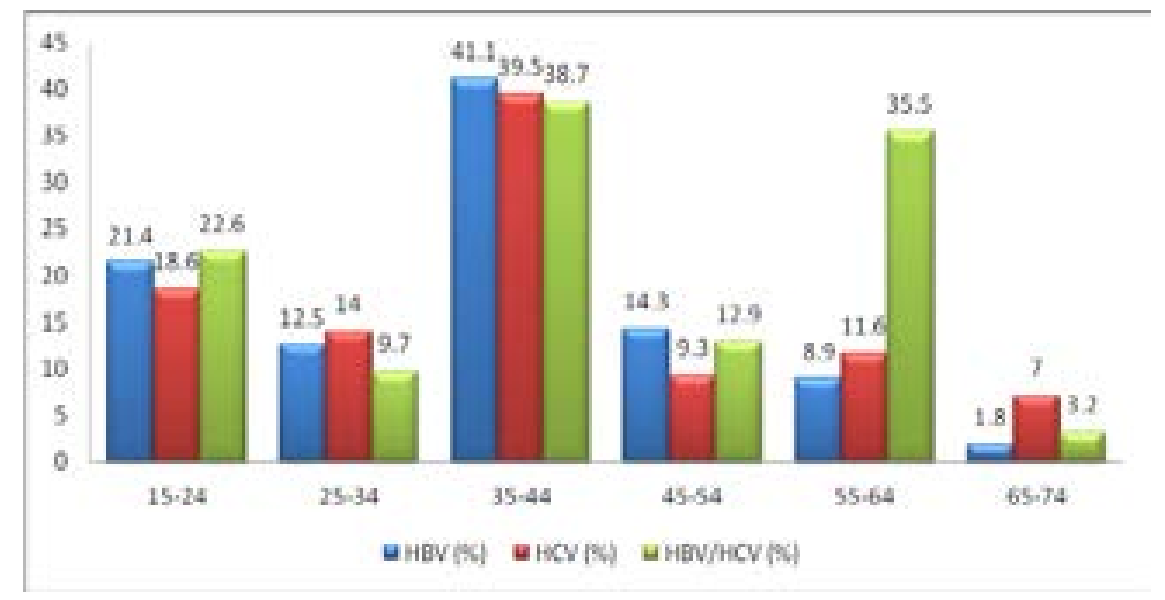

Figure 2: Age-related seroprevalence of $\mathrm{HIV} / \mathrm{HBV} / \mathrm{HCV}$ triple infections

The age-related seroprevalence of $\mathrm{HIV} / \mathrm{HBV} / \mathrm{HCV}$ is shown in Figure 2. Triple seropositivity of HIV/HBV/ $\mathrm{HCV}(38.7 \%)$ was higher in age group 35-44 years than in others. However, no significant variance $(p>0.05)$ existed between age and triple infections of $\mathrm{HIV} / \mathrm{HBV} /$ HCV.
Figure 3 shows CD4+ lymphocytes cells of HIV-infected subjects before and after initiation of ART. It showed that CD4+ lymphocytes cells at the initial visit before commencement of the antiretroviral therapy (ART) with $<200$ cells $/ \mu$ l were $73(39.9 \%)$ and subjects having CD4+ lymphocytes cells $>500$ cells/ $\mu$ l were $46(25.1 \%)$. 


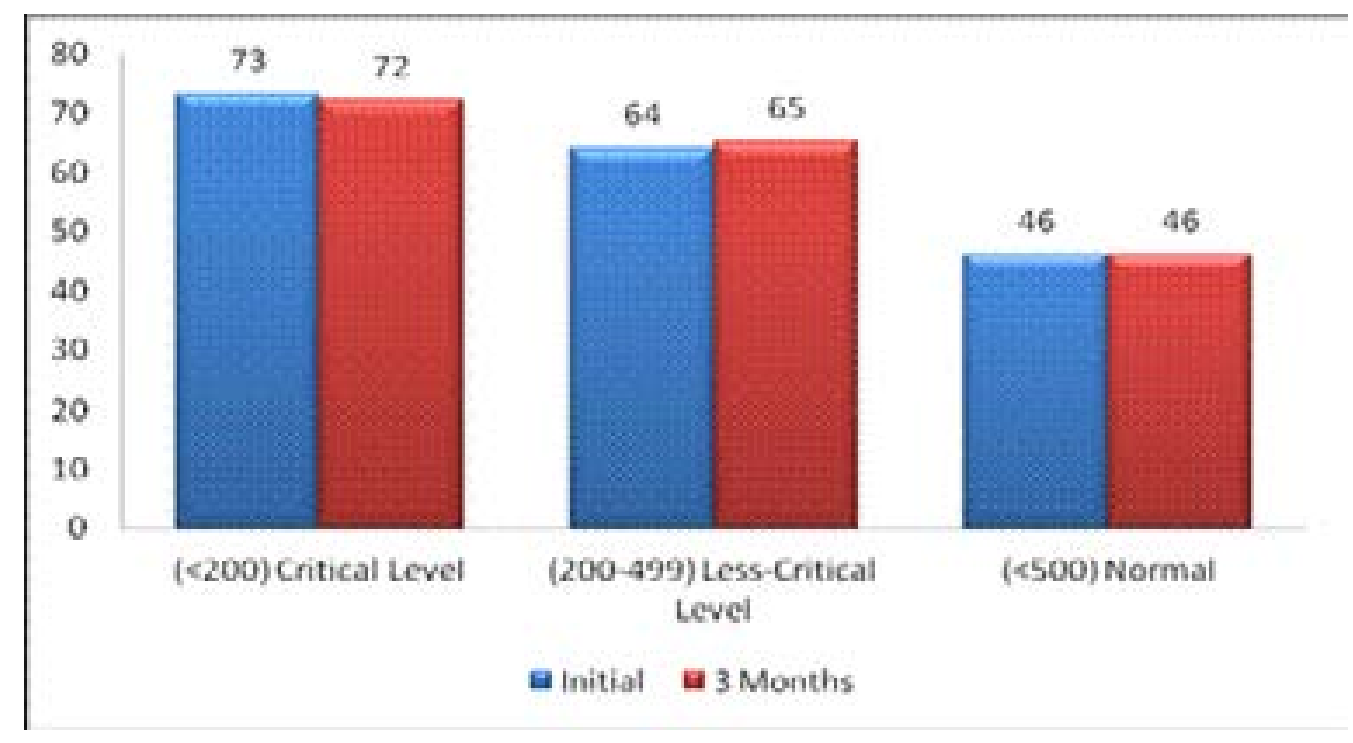

Figure 3: CD4 Count of HIV-Infected subjects before and after Initiation of ART

CD4+ lymphocytes cells after 3 months of initial visit to the ART clinic showed that there was a marginal decrease among individual with CD4+ lymphocytes cells $[72(39.9 \%)]$ and marginal increase with those CD4+ lymphocytes cells between 200-499 cells/ $\mu$ l [65(35.5\%] and individual with CD4+ lymphocytes cells of $>500$ cells $/ \mu \mathrm{l}$ were same as the initial visit [46(25.1\%)]. Furthermore, CD4+ lymphocytes cells after 6 months of initial visit to the ART clinic showed that there was a marginal decrease in subjects with CD4+ lymphocytes cells $<200$ cells $/ \mu 1[70(38.3 \%)]$ and subjects having CD4+ lymphocytes cells of 200-499 cells/ $\mu$ l were $62(33.3 \%)$. Subjects with CD4+ lymphocytes cells of $>500$ cells $/ \mu$ l increased to $52(28.4 \%)$ showing a positive impact on the CD4+ lymphocytes cells on the basis of consistent rise in the use of ART (Figure 3).

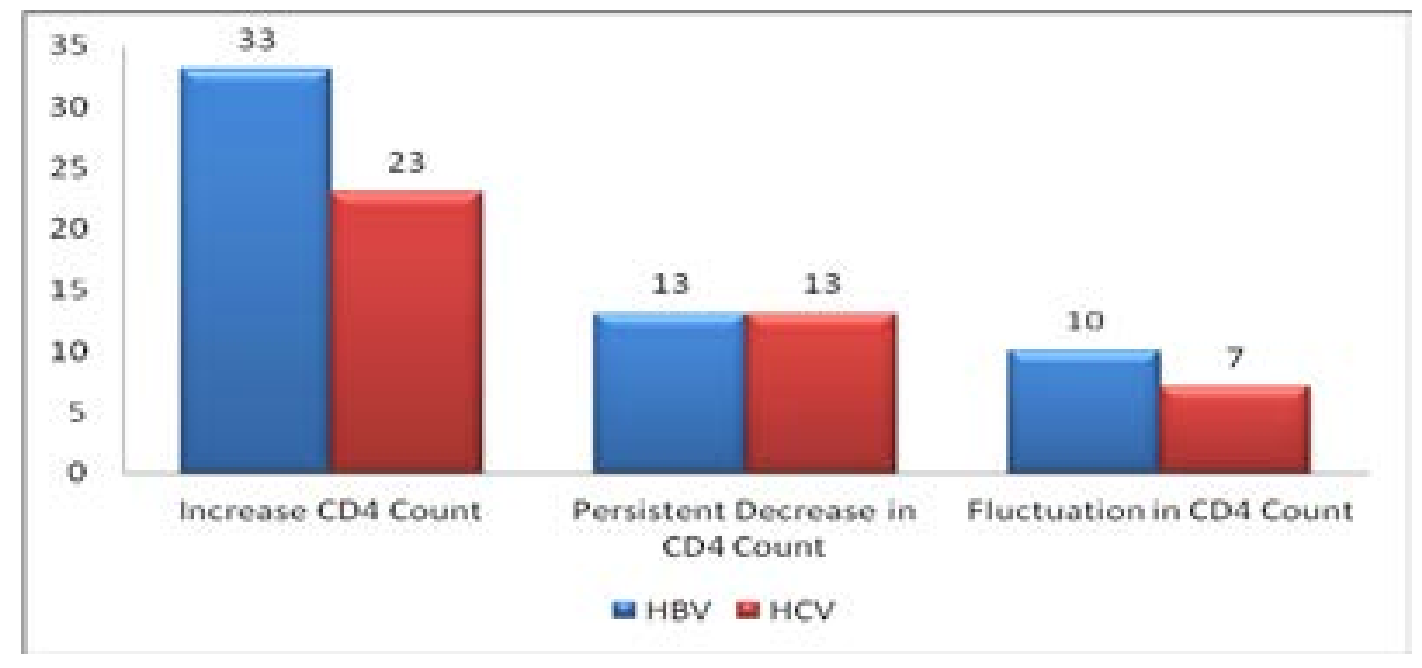

\section{Figure 4: CD4 Count Progression in relation to seroprevalence of $\mathrm{HIV} / \mathrm{HBV} / \mathrm{HCV}$ triple infections}

This difference is also statistically associated $(\mathrm{P}<0.05)$. Figure 4 shows CD4+ lymphocytes cells progressions in relation to HIV-HBV-HCV triple infections among the subjects. It showed a progression of CD4+ lympho- cytes cells among subjects with HIV-HBV-HCV triple infections $[17(55.8 \%)]$. Significant difference $(p<0.05)$ existed between CD4+ lymphocytes cells progressions of $\mathrm{HIV}$-infected subjects and $\mathrm{HIV} / \mathrm{HBV} / \mathrm{HCV}$ triple infections (Figure 4). 


\section{Discussion}

Several studies have proposed that human immunodeficiency virus can fast-track the usual sequence of long-lasting $\mathrm{HCV}$ and/or $\mathrm{HBV}^{13}$. Earlier studies devise that persons with long-lasting HCV/HBV and HIV will experience swift advancement besides being prone to death in comparison with non-HIV infected persons ${ }^{13}$. Contrariwise, the consequence of $\mathrm{HCV}$ and/or HBV on HIV infection remains indistinct ${ }^{13,38,50-51}$. Dual or triple infections of HIV and hepatitis viruses have considerably amplified disease and death rates of HIV and AIDS infected-persons $s^{13,38,50-51}$.

Triple infections are thus rising menace in Nigeria and cautious attention is needed due to its adversarial consequences on HIV treatment reaction ${ }^{8}$. Thus, it became necessary to estimate the seroprevalence of triple infections with $\mathrm{HIV} / \mathrm{HBV} / \mathrm{HCV}$, particularly amid groups known to be a high-risk populace of dual or triple infections. The present study aimed at determining the seroprevalence of $\mathrm{HIV} / \mathrm{HBV} / \mathrm{HCV}$ triple infections among HIV-infected individuals in Abeokuta, Nigeria. The study also aimed at defining the impact of these infections on CD4+ lymphocytes cells among HIV positive persons as access to antiretroviral therapy advances across the Nigerian nation.

Of the 183 HIV-infected subjects used in this study, 152(83.1\%) had HIV mono infection and 31 (16.9\%) had $\mathrm{HIV} / \mathrm{HBV} / \mathrm{HCV}$ triple infections. Previous studies in Nigeria had reported varying seroprevalences of $\mathrm{HIV} / \mathrm{HBV} / \mathrm{HCV}$ infections. Forbi et al. ${ }^{8}$ had reported an overall $\mathrm{HIV} / \mathrm{HBV} / \mathrm{HCV}$ prevalence of $7.2 \%$. A $3.9 \%$ seroprevalence of $\mathrm{HIV} / \mathrm{HBV} / \mathrm{HCV}$ was reported by Balogun et al. ${ }^{52}$ and $6.5 \%$ seroprevalence was reported by Okeke et al. ${ }^{53}$.

Higher seroprevalence of $\mathrm{HIV} / \mathrm{HBV} / \mathrm{HCV}$ triple infections in males than their female colleagues. Higher seroprevalence was recorded among age groups 35-44 years than in other age groups. This is in consonance with what was reported previously in the Northern Nigeria $^{16,54}$ and elsewhere in the world ${ }^{32,55-56}$. This may be due to fact that males at age group are most sexually active. Elsewhere, the triple infection rates of $19.1 \%$ and $10.4 \%$ was reported in China and Myanmar respectively ${ }^{13}$. A seroprevalence of $1.83 \%$ was reported by Agarwal et al. ${ }^{57}$. Musyoki et al. ${ }^{58}$ reported $29.4 \%$ prevalence of HIV/HBV/HCV infections in South Africa. Moreover, it has been indicated that the dual infections of $\mathrm{HIV} / \mathrm{HBV}$ and $\mathrm{HIV} / \mathrm{HCV}$ ) or triple infections of
$\mathrm{HIV} / \mathrm{HBV} / \mathrm{HCV}$ is most common, though the dual or triple infections rates varies liable to risk groups, type of exposure involved and geographic regions ${ }^{13,59-61}$.

The usual antiquity of $\mathrm{HBV}$ is identified to be intricated by HIV dual infections nevertheless the influence of HBV on the aftermath of persons infected with HIV-1 is contentious ${ }^{8,63}$. There was flawless clue of amplified HCV infection in HIV positive persons in Nigeria. It is also well-known that $\mathrm{HIV} / \mathrm{HCV}$ dual positivity fasttrack patients rapidly to AIDS defining clinical event, end-stage liver disease and death ${ }^{8,39,63}$. Unfortunately at this time, only $\mathrm{HBV}$ vaccine is available, HIV vaccine is under way and no active vaccine against $\mathrm{HCV}^{8}$.

The CD4+ lymphocytes values of 183 confirmed HIV positive persons were counted by means of a superior fluorescence activated cell sorter system. The result indicates that most of the subjects were diagnosed when the CD4+ lymphocytes cells were $<200$ cells $/ \mathrm{ml}$. The CD4+ lymphocytes cells of HIV/HBV/HCV triple infected subjects were significantly lower $(\mathrm{P}<0.05)$ than those with HIV mono infection only. The details for the drop in CD4+ level is unclear however, it is recognised that there is disparity in outlying blood T-lymphocyte subsets and commotion in cellular immunity in the persons with long-lasting hepatitis $\mathrm{B}^{64}$. Also, HIVHBV-HCV triple infected individuals responded poorly to the ART treatment than those with HIV mono infection only. This finding is in agreement with previous reports ${ }^{16,32,65-67}$.

This study also showed a progression of CD4+ lymphocytes cells among subjects with HIV-HBV-HCV triple infections [17(55.8\%)]. The consistency and regular use of antiretroviral therapy as prescribed by the counselors improved the immunity of the HIV infected individual as indicated by progressive increase in the CD4+ lymphocytes cells which is in support with previous reports ${ }^{3,9,30,32,68-70}$. Forbi et al. ${ }^{8}$ in a similar study, reported that rise in CD4+ cells after HAART does not alter in persons with triple infections of $\mathrm{HIV} / \mathrm{HBV} / \mathrm{HCV}$ however, HCV seems to deter virological response to ART.

\section{Conclusion}

As far as we know, there are few reports on the triple positivity of $\mathrm{HIV} / \mathrm{HBV} / \mathrm{HCV}$ infections in the highly HIV infected populations in Nigeria. This study further endorses the possibility and endemicity of HBV and $\mathrm{HCV}$ dual or triple infections and increased infection in 
HIV-infected individuals. Planned prevention, screening and treatment are needed to reduce further transmission and morbidity of these infections. Intensified $H B V$ vaccination program is also advocated in Nigeria which is known to be able to substantially diminish the occurrence of HBV infections.

This study has also demonstrated that dual or triple infections of HIV and hepatitis viruses (HBV and/or $\mathrm{HCV}$ ) are on the rise in Nigeria. It seems to decline the CD4+ lymphocytes cells of patients who have triple positivity of HIV, HBV, and HCV. It also showed that consistent and prolong use of antiretroviral therapy will influence positively CD4+ lymphocytes cells of HIV-infected individuals. Thus, we call for sustainable educational promotion programmes on the means of acquisition and spread of HIV, HBV and HCV, as well as increasing $\mathrm{HBV}$ vaccinations in order to curtail the spread of HIV, HBV and HCV in Abeokuta, Nigeria. However, further studies on the mechanism by which the HBV and HCV act as a cofactor for the HIV-infected individual is thus warranted in this part of the country.

\section{References}

1. Hepatitis B Foundation Princeton Workshop Viral Triple Threat: HBV with HCV/HIV Co-Infections Liver Disease November 12-13, 2008 Princeton, New Jersey

2. Harcourt G, Gomperts E, Donfield S, Klenerman P, the Hemophilia Growth and Development Study. 2006. Diminished frequency of hepatitis $C$ virus specific interferon c secreting CD4+ $\mathrm{T}$ cells in human immunodeficiency virus/hepatitis $\mathrm{C}$ virus coinfected patients. Gut 2006;55:1484-1487. doi: 10.1136/gut.2005.083758 3. Mohsen, A.H., Easterbook, P. and Taylor, C.B. (2002). Hepatitis C and HIV-1 co-infection. Gut 2002. 51: 605-608.

4. Martin-Carbonero, L., Benhamou, Y. and Puoti, M. (2004). Incidence and Predictors of severe liver fibrosis in human immunodeficiency virus-infected patients with chronic hepatitis C: European collaborative study. Clinical Infection Disease. 38: 128-133.

5. Santiago-Munoz P Roberts S, Sheffield J, McElwee B, Wendel GD 2005. Prevalence of hepatitis B and C in pregnant women who are infected with human immunodeficiency virus. Am J Obstr Gyn 193 (Suppl. 3): 1270. 6. Hussain T., K.K. Kulshreshtha, Shikha Sinha, V.S. Yadav, V.M. Katoch. HIV, HBV, HCV, and syphilis co-infections among patients attending the STD clinics of district hospitals in Northern India. International Journal of Infectious Diseases, 2006; 10: 358-363

7. Oje OJ, Sule WF and Famurewa D. Dual Positivity of Hepatitis B Surface Antigen and Anti-Hepatitis C Virus Antibody and Associated Factors Among Apparently Healthy Patients of Ekiti State, Nigeria. Viral Immunology, 2012; 25(6): 448-455

8. Forbi JC, S Gabadi, R Alabi, HO Iperepolu, CR Pam, PE Entonu, SM Agwale. The role of triple infection with hepatitis B virus, hepatitis $C$ virus, and human immunodeficiency virus (HIV) type-1 on CD4+ lymphocyte levels in the highly HIV infected population of North-Central Nigeria. Mem Inst Oswaldo Cruz, Rio de Janeiro, 2005; 102(4): 535-537

9. Benhamou, Y., Fleury, H. and Trimoulet, P. (2006). Anti-hepatitis B virus efficacy of tenofovir disopnoxil fumarete in HIV-infected patients. Histopathology. 43: 548-555.

10. McHutchison, J.G., Gordon, S.C. and Schiff, E.R. (2009). Interferon $\mathrm{a}-2 \mathrm{~b}$ or in combination with ribavirin as initial treatment for chronic hepatitis C. New England Journal of Medicine. 339: 1485-92.

11. Maier I, Wu GY. Hepatitis C and HIV co-infection: a review. World J Gastroenterol. 2002;8:577-579.

12. Aceijas C, Rhodes T. Global estimates of prevalence of HCV infection among injecting drug users. Int J Drug Policy. 2007;18:352-358.

13. Zhou Y-H, Liu F-L, Yao Z-H, Duo L, Li H, et al. Comparison of HIV-, HBV-, HCV- and Co-Infection Prevalence between Chinese and Burmese Intravenous Drug Users of the China-Myanmar Border Region. PLOS ONE, 2011; 6(1): e16349. doi:10.1371/journal. pone.0016349

14. Saravanan S, Velu V, Kumarasamy N, Nandakumar $\mathrm{S}$, Murugavel KG, et al. Coinfection of hepatitis B and hepatitis C virus in HIV-infected patients in south India. World J Gastroenterol 2007. 2007;13:5015-5020.

15. Koziel MJ, Peters MG. Viral hepatitis in HIV infection. N Engl J Med. 2007;356:1445-1454

16. Nwokedi, E.E., Ilyasu, Z., Emokpae, M.A., Dutse, A.I. and Taura, A.A. (2006). Hepatitis $C$ virus infection among Teaching Hospital patients in Kano, Nigeria: A retrospective study. Annals African Medicine. 5(4): 18587.

17. De Paola LG, Carpenter WM. Blood-borne pathogens: current concepts. Compend Contin Educ Dent 2002;23:207-10.

18. Bigger CB, Brasky KM, and Lanford RE: DNA microarray analysis of chimpanzee liver during acute resolving hepatitis $\mathrm{C}$ virus infection. J. Virology, 2001;75:7059-7066. 
19. Thimme R, Bukh J, Spangenberg HC, et al.: Viral and immunological determinants of hepatitis $C$ virus clearance, persistence, and disease. Proc Natl Acad Sci USA 2002;99: 15661-15668.

20. Su AI, Pezacki JP, Wodicka L, et al.: Genomic analysis of the host response to hepatitis $\mathrm{C}$ virus infection. Proc Natl Acad Sci USA 2002;99:15669-15674.

21. Wieland S, Thimme R, Purcell RH, and Chisari FV: Genomic analysis of the host response to hepatitis B virus infection. Proc Natl Acad Sci USA 2004;101:6669_ 6674.

22. Nystrom J: Functional role of T-cell activation in viral hepatitis. Department of Laboratory Medicine, Karolinska Institutet, Stocholm, Sweden, Thesis, 2009, pp 1-65.

23. Corr M, Lee DJ, Carson DA, and Tighe H: Gene vaccination with naked plasmid DNA: mechanism of CTL priming. J Exp Med 1996;184:1555-1560.

24. Shen L, and Rock KL: Priming of T cells by exogenous antigen cross-presented on MHC class I molecules. Curr Opin Immunol 2006;18:85-91.

25. Maini MK, Boni C, Lee CK, et al.: The role of virus-specific $\mathrm{CD} 8+$ cells in liver damage and viral control during persistent hepatitis B virus (HBV) infection. J Exp Med 2000; 191:1269-1280.

26. Strader DB, Wright T, Thomas DL, and Seeff LB: Diagnosis, management, and treatment of hepatitis C. Hepatology 2004;39:1147-1171.

27. Gerlich WH: Diagnostic problems caused by HBs Ag mutants: A consensus report of an expert meeting. Intervirology 2004;47:310-313.

28. Locarnini S: Molecular virology of hepatitis B virus. Semin Liver Dis 2004;24(Suppl 1):3-10.

29. Hepatitis C Support Project: HBV: how to interpret hepatitis B antibody and viral tests, 2008, www.hbvadvocate.org

30. Godsworth, N.J., Cooper, D.A. and Disnovan, B. (2009). The influence of human immunodeficiency virus type I infection on the development of the hepatitis B virus carrier state. Journal of Infections Disease, 163: 1138-1140.

31. Micropathology Limited (2013). CD4 Testing. University of Warwick Science Park, Venture Centre, Sir William Lyons Road, Coventry CV4 7EZ. Website: www.micropathology.com

32. Michael, D., Dieterich, D. and Touly, M. (2012). Uses of CD4 Cell Count in Human immunodeficiency virus. Haematology. 45: 2-15.

33. Rathbun RC, Lockhart SM, Stephens JR 2006. HIV treatment guidelines - An overview. Curr Pharm Dis 12: 1045-1063.
34. Ikpeme EE, Etukudo OM, Ekrikpo UE. Seroprevalence of HBV and HIV co-infection in children and outcomes following highly active antiretroviral therapy (HAART) in Uyo, South-South Nigeria. African Health Sciences 2013; 13(4): 955 - 961

35. Feld JJ, Ocama P, Ronald A 2005. The liver in HIV in Africa. Antivir Ther 10: 953-965.

36. Mosunjac MB, Tadros T, Beach R, Majumdar B. Cervical schistosomiasis, human papillomavirus (HPV), and human immunodeficiency virus (HIV): a dangerous co-existence or co-incidence? Gynecol Oncol 2003;90:211-4.

37. Ramia S, Klayme S, Naman R. Infection with hepatitis B and C viruses and human retroviruses (HTLV-I and HIV) among high-risk Lebanese patients. Ann Trop Med Parasitol 2003;97: 187—92.

38. Thio CL. Hepatitis B and human immunodeficiency virus coinfection. Hepatology. 2009;49:S138-S145.

39. Greub G 2000. Clinical progression, survival, and immune recovery during antiretroviral therapy in patients with HIV-1 and hepatitis C virus co-infection: the Swiss HIV Cohort Study. Lancet 356: 1800-1805.

40. Greub G, Ledergerber B, Battegay M, et al. Clinical progression, survival, and immune recovery during antiretroviral therapy in patients with HIV-1 and hepatitis C virus coinfection: the Swiss HIV Cohort Study. Lancet 2000; 356:1800-5.

41. De Luca A, Bugarini R, Lepri A, et al. Coinfection with hepatitis viruses and outcome of initial antiretroviral regimens in previously naive HIV-infected subjects. Arch Intern Med 2002; 162:2125-32.

42. Miller MF, Haley C, Koziel MJ and Rowley CF. Impact of Hepatitis C Virus on Immune Restoration in HIV-Infected Patients Who Start Highly Active Antiretroviral Therapy: A Meta-analysis. Clin Infect Dis. (2005) 41 (5): 713-720.

43. Macias J, Pineda JA, Lozano F, et al. Impaired recovery of CD4+ cell counts following highly active antiretroviral therapy in drug-naive patients coinfected with human immunodeficiency virus and hepatitis $C$ virus. Eur J Clin Microbiol Infect Dis 2003; 22:675-80.

44. Rancinan C, Neau D, Saves M, et al. Is hepatitis C virus co-infection associated with survival in HIV-infected patients treated by combination antiretroviral therapy? AIDS 2002; 16:1357-62.

45. Chung RT, Evans SR, Yang Y, et al. Immune recovery is associated with persistent rise in hepatitis $C$ virus RNA, infrequent liver test flares, and is not impaired by hepatitis C virus in co-infected subjects. AIDS 2002; 16:1915-23. 
46. Klein MB, Lalonde RG, Suissa S. The impact of hepatitis $C$ virus coinfection on HIV progression before and after highly active anti-retroviral therapy. $J A c-$ quir Immune Defic Syndr 2003; 33:365-72.

47. Lincoln D, Petoumenos K, Dore GJ. HIV/HBV and $\mathrm{HIV} / \mathrm{HCV}$ coinfection, and outcomes following highly active antiretroviral therapy. HIV Med 2003; 4:241-9. 48. Sulkowski MS, Moore RD, Mehta SH, Chaisson RE, Thomas DL. Hepatitis $\mathrm{C}$ and progression of HIV disease. JAMA 2002; 288:199-206.

49. Odemuyiwa SO, Mulders MN, Oyedele OI, Ola SO, Odaibo GN, Olaleye DO, Muller CP 2001. Phylogenetic analysis of new hepatitis B virus isolates from Nigeria supports endemicity of genotype $\mathrm{E}$ in West Africa.J Med Virol 65: 463-469.

50. Sulkowski MS. Viral hepatitis and HIV coinfection. J Hepatol. 2008;48:353-367.

51. Rotman Y, Liang TJ. Coinfection with hepatitis C virus and human immunodeficiency virus: virological, immunological, and clinical outcomes. J Virol. 2009;83:7366-7374.

52. Balogun TM, Emmanuel S, Ojerinde EF. HIV, Hepatitis $\mathrm{B}$ and $\mathrm{C}$ viruses' coinfection among patients in a Nigerian tertiary hospital. Pan Afr Med J. 2012; 12: 100

53. Okeke TC, Obi SN, Okezie OA, Ugwu EO, Akogu SP, Ocheni S, Ezenyeaku CC. Coinfection with hepatitis $\mathrm{B}$ and $\mathrm{C}$ viruses among HIV positive pregnant women in Enugu south east, Nigeria. Niger J Med. 2012; 21(1):57-60

54. Akolo CO. Impact of Hepatitis B co-infection on the CD4 Cell counts of HIV/AIDS patients on Highly Active Anti Retroviral Therapy at the Jos University Teaching Hospital. 4th National Conference on HIV/ AIDS in Nigeria, 2005. Abuja, Nigeria.

55. Lincoln, D., Petoumenos, K. and Dore, G.J. (2003). $\mathrm{HIV} / \mathrm{HBV}$ and HIV/HCV co-infection and outcomes following high active antiretroviral therapy. Human Immunodeficiency Virus Medicine. 4: 241-249.

56. Muhammad, M.A., Sohail, Z.Z., Shelzad, S., Salmaan, M.A. and Shamim, S. (2009). Hepatitis B infections. Virology Journal. 4: 63-69.

57. Agarwal N, Dubey U, Agarwal A, Jaiswal R. Hepatitis B or Hepatitis C: The Bigger Threat in Multiple Infected HIV Positive Blood Donors. Journal of Clinical and Diagnostic Research, 2011; 5:766-768.

58. Musyoki AM, Msibi TL, Motswaledi MH, Selabe SG, Monokoane TS and Mphahlele MJ. Active co-infection with HBV and/or HCV in South African HIV positive patients due for cancer therapy. J. Med. Virol. 87:213-221, 2015.

59. Zhang C, Yang R, Xia X, Qin S, Dai J, et al. High prevalence of HIV-1 and hepatitis C virus coinfection among injection drug users in the southeastern region of Yunnan, China. I Acquir Immune Defic Syndr. 2002;29:191-196.

60. Wang YC, Xu SH, Li XH, Song AJ, Jia XR, et al. A study on the prevalence rates of human immunodeficiency virus, hepatitis $B$ virus and hepatitis $C$ virus infections in intravenous drug users. Zhonghua Liu Xing Bing Xue Za Zhi. 2006;27:777-779.

61. Bao YP, Liu ZM. Systematic review of HIV and $\mathrm{HCV}$ infection among drug users in China. Int J STD AIDS. 2009;20:399-405.

62. Rockstroh JK 2006. Influence of viral hepatitis on HIV infection. J Hepatol 44 (Suppl. 1): S25-27.

63. Monga HK, Rodriguez-Barradas MC, Breaux K, Khattak K, Troisi CL, Velez M, Yoffe B 2001. Hepatitis $\mathrm{C}$ virus infection related morbidity and mortality among patients with human immunodeficiency virus infection. Clin Infect Dis 33: 240-247.

64. Tian Y, Qiu ZF, Li TS 2005. Difference and significance of peripheral blood T-lymphocyte subsets in patients with chronic hepatitis B and asymptomatic HBV carriers. Zhonghua yi xue za zhi 14: 3354-3358.

65. Ayodele, O.E. and Salako, B.L. (2003). Hepatitis C virus and chronic renal disease. African Journal of Medical Sciences 32: 287-291.

66. Backus, L.I., Boothroyd, D. and Deyton, L.R. (2005). HIV, Hepatitis C and HIV/hepatitis C virus co-infection in vulnerable populations. Acquired Immunodeficiency Syndrome. 19(3): S13-19.

67. Hisada, M., O'Brien, T.R., Rosenberg, P.S. and Goedert, J.J. (2009). Virus load and risk of heterosexual transmission of human immunodeficiency virus and hepatitis C virus by men with hemophilia. Journal of Infectious Diseases. 181: 1475-1478.

68. Greub, G., Ledergerder, B. and Bathegay, M. (2002). Clinical progression, survival and immune recovery during antiretroviral therapy in patients with HIV I and hepatitis C virus co-infection: the Swiss HIV control study. Lancet. 356: 1800-1805.

69. Macias, J., Pineda, J.A. and Lozano, F. (2003). Impaired recovery of CD4 cell counts following highly active antiretroviral therapy on drug-naïve patients co-infected with human immunodeficiency virus and hepatitis C virus. European Journal of Clinical Microbiology Infectious Diseases. 22: 675-680.

70. Odama, L.E., Mohammed, S.E. and Audu, I.G. (2005). Prevalence of Hepatitis C virus amongst HIV infected patients and blood donors in Nigeria. 4th National conference on HIV/AIDS in Nigeria 2005. Abuja, Nigeria. 